\title{
ANALYSIS OF THE FINANCIAL MARKET AS A DRIVING FORCE OF THE REGIONAL ECONOMY IN THE CONDITIONS OF PRE- AND POST - PANDEMIC
}

(iD) Asie Tsintsadze ${ }^{1}$, Doctor of Economics, Professor; Irina Vashakmadze ${ }^{2}$, Doctor of Economics, Associate ; Irina Tavadze ${ }^{3}$, Doctor of Economics, Assistant Professor; Lilit Meloyan-Phutkaradze ${ }^{4}$, Doctor of Economics, Assistant Professor

1,2,3,4 Faculty of Economics and Business, Batumi Shota Rustaveli State University

\begin{abstract}
The pandemic has negatively affected the financial sector, as well as the real sector of the economy, both losses and credit risks in the financial market have increased on the background of the economic activity slowed-down. In 2019, the credit activity was high, however after the spread of the virus the activity slowed down significantly. This is natural, as due to the suspension of production -organizing, the unemployment has increased. Volume of the direct foreign investments has decreased by $42 \%$. Government of Georgia has developed an anti-crisis plan, important part of which is about the mitigation of deteriorated living conditions caused by the unemployment, whereas the National Bank of Georgia has pursued monetary and fiscal policies for the purpose of mitigation of negative influence of COVID-19 on the country's financial sector and for the stimulation of the country's economy. In general, saving the business is considered as a priority. The current situation in the banking, insurance and stock markets and their role in the fight for maintaining the economic stability are analysed in the present article. It is important to note that, the insurance sector is the part of the economic, which did not need financial assistance in a difficult situation, but due to the common socioeconomic situation, diseases caused by the stressful conditions of the population, it was necessary to make significant changes in the list of the insurance services. This, to the extent had led to some unforeseen costs, which had affected the financial conditions of the companies. According to the evaluation of the credit rating company -Fitch, the trustworthy policy implemented by the National Bank of Georgia, had played an important role in the maintenance of the financial stability and Georgian sovereign rating remained unchanged, at BB level, however, what parameters and in what area was the rating maintained and how the positions of the main players in the financial market have been changed, are the main directions of the article's research.
\end{abstract}

Key words: pandemic, financial market, credit risk, investments, insurance, unemployment, rating, stock exchange.

JEL code: G21; G22

\section{Introduction}

The concern of the governments in developing countries is to find the ways to develop the economy. Since 1990, many mistakes were made in the post-Soviet countries by stereotyping the experience of other countries, which slowed down the pace of economic development. While developed countries focused on strengthening the financial sector, the financial institutions in Georgia were newly formed in Georgia, perfection of which was hindered by the crises arising at different times.

The right way of economic development goes through the financial market, the participating financial institutions will redistribute free cash flows of economic entities between the economic sectors and will ensure the supply of additional financial resources for the reproduction, which is the necessary condition for maintaining the continuity of the production process. The crucial role in the development of the financial market belongs to the stock market, which promotes the investment activity both by the existing domestic capital as well as by the inflow of foreign investment. Well-regulated financial market must already exist in the country for the foreign investors, which is the "Trustworthy way for the Development of Economy". According to the "Theory of Financial Markets' Development", the stock markets stimulate the economic growth, to the extent that they are integrated into the "Institutional Matrix", which means the functioning of developed, sustainable market financial institutions in such political, economic and ideological environment, where the relationships are built on the market principles and the State becomes the party 
of the Agreement (Klaus Weber Gerald F. Davis and Michael Lounsbury, Financial market theory of development, Wikipedia, the free encyclopedia).

The goal of the present article is to analyse the role of the financial market in the economy of a developing country, sustainability of the financial institutions functioning in the institutional matrix during the pre-and-post pandemic period. The main players of the financial market -banking institutions, insurance institutions and securities markets as the mechanisms for development of above listed institutions and vice versa, are selected as the study objects.

The level of financial market's development is determined by the effective performance of financial institutions' functional purpose. The main player in this system is the banking sector, which serves to provide additional recourses for the reproduction. If it is achieved, the field of production expands, gross domestic product grows in the country and the living standards of the population rise. The free cash flows with the participation of financial institutions move between the economic entities, as a result, domestic and foreign economic activities are activated. Activity of each financial institution is oriented to obtain the maximal profit, the strategic plan of the banking sector itself is built on the accumulation of a large amount of cash resources for the purpose of achievement its own goal.

\section{Research Findings and Discussion}

The National Bank of Georgia had pursued monetary and fiscal policies for the mitigation of the negative influence of COVID-19 on the country's financial sector and for the stimulation of the country's economy; in particular

1) uninterrupted supply of liquid cash resources to various sectors;

2) development of the temporary supervision plan;

3) expansion of the program supported by the International Monetary Fund.

As a result of the financial stability, policy was pursued during the recent years, Georgia's financial system faced the shocks caused by COVID-19 pandemic, prepared and maintained its sustainability. In the recent years, the requirement of the additional capital imposed by the National Bank and the profit obtained by the commercial banks allowed banks to accumulate sufficient capital buffers to deal with the stressful situations. Herewith, during the pre-crisis period, the National Bank took a number of macro prudential measures in order to reduce excess debts of the households and loans dollarization. This had promoted the decrease of vulnerability existing in the nonfinancial sectors and increased the sustainability of the financial sectors towards the shocks. As a result of the pandemic, it was expected to increase the share of inactive loans, however, the commercial banks created the reserves for possible losses in advance. Correspondingly, the financial sector had enough resource to uninterruptedly continue lending to the economy.

However, it should be noted that the pandemic, along with the real sector of the economic, had also a negative impact on the financial sector, both losses and credit risks in the financial market had been increased on the background of the economic activity slowed-down. The recession caused by the pandemic is different from the global financial crisis of the years 2008-2009 by its nature. In this case the source of the recession is not the real and financial sector of the economic, but the restrictions introduced in order to avoid the rapid spread of the virus. The banking system accounts for over 90 percent of Georgia's financial sector. FSI's (Financial Stress Index) index basically combines the indicators of profitability of banking sector, interest spread, capital and assets. Despite the measures taken by the National Bank of Georgia, during the crisis, the banking system's liquidity needs could not be delivered, which had increased the risk of liquidity in the bank system and forced the banks to reduce crediting even more sharply. 
All of this, in the end, was reflected in a significant decline in lending to the economy. Unlike 2008, in 2019, the annual growth of loans was on average within 20 percent. After the start of the pandemic, the growth of loans slowed down to 3 percent.

The crisis of the year 2020 once more clearly shows the importance of the country's economic stability against the shocks. In 2019, the credit activity was high and by the end of the year the tempo of the annual growth of loans (by excluding exchange rate effect) amounted to16 percent (Figure 1).

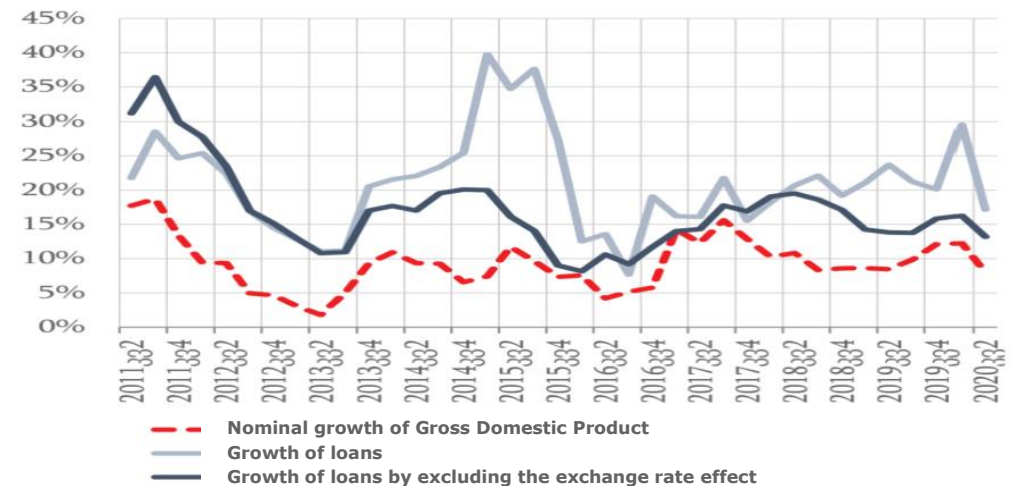

Source: National Bank of Georgia

Figure 1. Annual growth rate of loans

15 commercial banks operating in Georgia received a total loss in the amount of GEL 747 million in the first quarter of 2020. The main determinant of the loss was the reservation of 1.2 billion GEL for possible losses by the side of banks. Totally, Georgian commercial banks had reserved 1.22 billion GEL in the buffers of "Assets' Possible Losses", which due to the expected crisis reflects the number of possible losses on the loans. This is the amount which the banks reflected as the possible losses due to the crisis arisen from the COVID-19 pandemic, however, directly their operative activity by the first quarter of 2020 was still profitable and 14 banks from those 15 obtained the net profit before making reservations.

Banks are reducing the issue of loans due to the expectation of potential loss. This, in turn, further slows down the economic activity and the negative spiral will be repeated.

In 2020, the profitability of commercial banks will be close to zero. The banks' sectors were characterized with high profitability before the pandemic, in 2019 the average return on equity (ROE) was within 18 percent (Figure 2). As a result of pandemic, the net profit became negative and it amounted minus 747 million GEL in the first quarter of the current year, which is 1.5 percent of total assets.

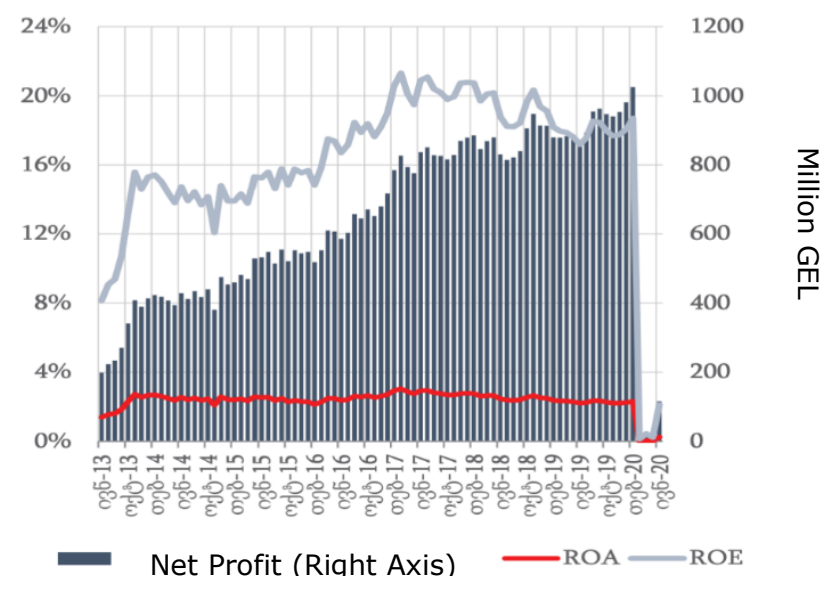

Source: National Bank of Georgia (annual financial stability report 2020)

Figure 2. Profitability of the bank sector 
It should be noted that, the negative profit during COVID-19 pandemic is conditioned by the reserves created for balancing the arisen negative expectations. Thanks to the high operating income, it is expected that, after the completion of pandemic, the banks will be able to make a profit by promoting the healthy and sustainable development of financial sector.

Influential rating Agency-Fitch, had left Georgia's sovereign credit rating and rating outlook unchanged - at a "BB" level with a negative perspective. It should be noted that in April, after Agency's previous assessment regarding Georgia's economic condition, Fitch decreased rating prospects or sovereign ratings for many countries. For example: rating company had worsened the rating for the US, Japan, Iceland, Macedonia, France, Austria, and reduced Canada's sovereign rating from AAA to AA +.

Fitch's Report in August 2020, on Georgia's sovereign rating, clearly reflects the Rating Company's positive assessment towards Georgia's economic policy, business environment, institutional strength and quality of governance.

Georgia's sovereign credit rating is supported by an attractive investment and business environment and a high degree of governance in comparison to the median indicators of BB category countries. A sequential and reliable policy framework promotes the country's stability against the external shocks. According to the Rating Agency's Report, a reliable and consistent policy framework had facilitated the stability of the Georgian economy against the shocks, maintained the macroeconomic stability and reduced the risks of current account deficit. The macro prudential measures taken by the National Bank contributed to the stability of the financial sector, whereas the limited foreign exchange interventions softened the exchange of currency fluctuations.

The insurance sector, differs from all other financial institutions by the specifics of its activities and its historical function is the protection from risks. In the modern period, it is not only limited to the function of population's insurance protection. Nowadays, the insurance companies are the owners of huge capitals and by placing them in the financial market, both the financial market as well as economics of the country will be developed.

It is represented in this way in the financial market of developed countries, however in the developing countries the use the investment portfolio of insurance sectors for the purpose of stability of financial market still remains the problem.

Two issues are revealed here: the first one is the stability of insurance business development in the country and the second one is the possibility of placing insurance capital in such financial instruments that will expand the economic capabilities of other business entities and increase the sustainability of insurance finances. Based on theoretical concepts and analysis of the insurance market, the article answers the hypothesis "A developed insurance market means a developed financial market." Penetration is one of the indicators of market development assessment "by the variety of products Georgian insurance market is still far away from European market, the reason of it is the low income of the population, the low level of risks awareness and insurance culture. Correspondingly, the share of insurance field in Gross Domestic Income in comparison to the European countries is very low $(1.18 \%)$, which is confirmed by the size of insurance penetration", the second indicator, which is directly defined by the insurance premium per capita, is the solidity of insurance. The indicator of insurance premium per capita in Georgia is the lowest among the European countries (Tsintsadze, Vashakmadze, Tavadze, Meloyan-Phutkaradze, 2020). In the current reporting year, the changes in the indicators cannot be made due to the spread of pandemic throughout the world and the attitude of population towards the insurance has deteriorated due to reduced incomes. Hence, for the determination of the role of the insurance industry in the capital of the financial market, the article has studied the investment activities of the insurance companies in the assets specified in the 
regulatory documents and problems have been identified by comparing the financial condition of companies before the pandemic with the results of operating under pandemic conditions.

For the analyses of investment activity, deposits of ten large banks and cash placed by the insurance companies have been used, by which the share of the insurance companies in the bank capital was determined. Data of 2015-2019 have been analysed and parallel to this, the amount of investment capital of the insurance sector before the pandemic was compared to the amount of capital in the conditions of the pandemic (2020).

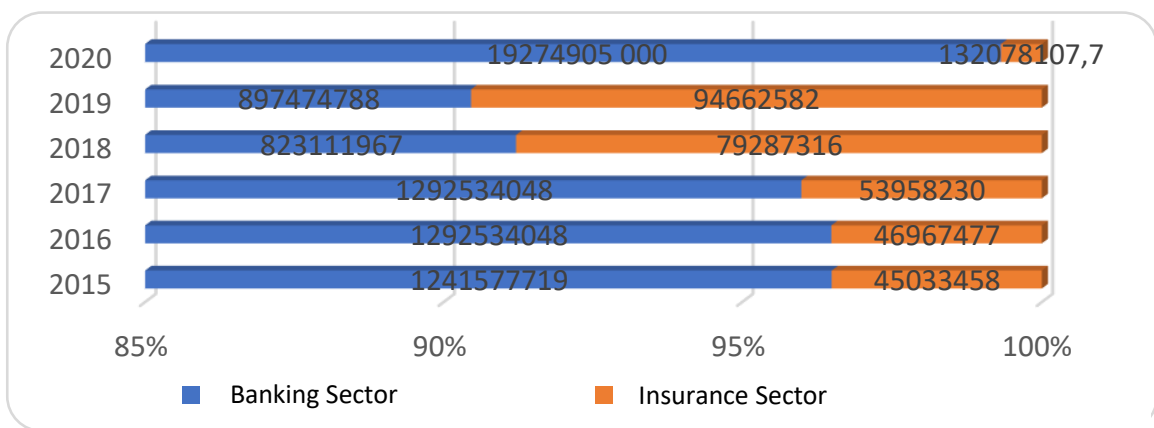

Source: National Bank of Georgia, Insurance Supervision Service

Figure 3. The share of insurance capital in bank deposits

The Figure 3 demonstrates that the share of insurance companies' deposits is very small in bank deposits (2015-2016- 4 \%; 2017-5.3 \%; 2018-9 \%; 2019 -9.8 \%; 2010-1 \%). Before the pandemic in 2018-2019, the investment potential of the insurance companies is within the 9-19\% (Figure 3). But in the pandemic condition it dropped to $1 \%$, however in the absolute value, the investment capital in 2020 has been increased 1.4 times, according to which the percentage indicator of the bank deposits have been decreased. Explanation of this phenomenon in our opinion is the following: the capital in the ownership of the legal entities was transferred from the stock market to the less risky banking sector, the growth of the insurance sector's investment potential in the pandemic year is due to the increase in demand of health and life risk insurance products. In particular: in 2020, compared to the previous year, the number of policies and correspondingly premiums attracted on the health insurance products during 9 months of the year 2020 had been increased 1.4 times compared to the data of 9 months of 201-1019. This was caused by the growth of pandemic risks. Due to the risky nature of insurance business, investing in highly capitalized financial instruments is important, such as "loan securities" (bonds) and privileged shares, flows of those had been carried out in the organized securities market of Georgia, OECD member countries and/or developed countries, but no more than $15 \%$ of the "amount of insurance reserves for investment", and also no more than $-10 \%$ in the non-organized market (The Order No 51/01 of the President of National Bank of Georgia "On approving the rules for determining the eligible assets and their structure to cover insurance reserves"). However, the reality is different, in particular, the insurance companies, due to the weak financial base, are not able to position themselves as the sellers and buyers of the securities in the securities market. Attraction of the additional financial recourses by issued stocks are risky for the insurance sector, as the sales problem will arise, in other words no one wants to invest their capital in high-risky enterprise securities. Figure 4 shows the profitability of the insurance market, which is not desirable. They cannot act as buyers of securities because they do not have the motivation to invest in long-term financial instruments due to the underdevelopment of accumulative life insurance. 


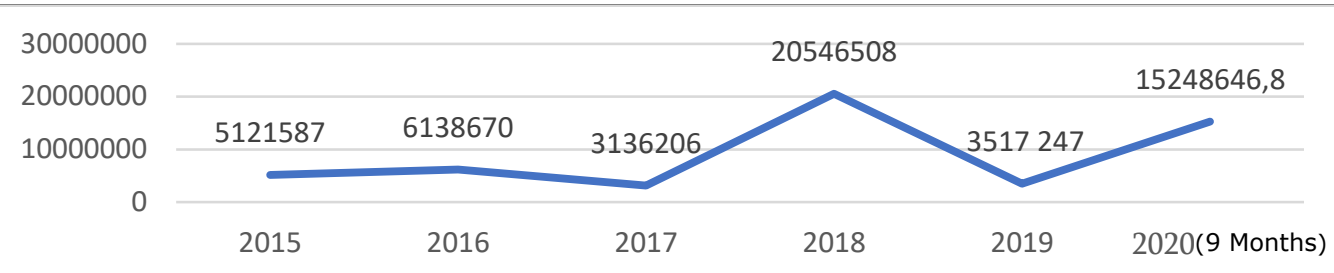

Annual Net Profit

\section{Source: Insurance Supervision Service of Georgia}

\section{Figure 4. Financial indicators of insurers}

Hypothesis: "Developed insurance market-developed financial market" means the investment of the insurance capital in the domestic and foreign financial market. For the evaluation of Georgian market in this direction, let's see the example of the state of investment of the insurance industry in the developed countries, in various assets

Table 1

The state of investments of the insurance industry in developed countries in various activities

\begin{tabular}{|c|c|c|c|c|c|c|}
\hline Countries & $\begin{array}{c}\text { Cash and } \\
\text { Deposit } \\
\text { (Million USD) }\end{array}$ & $\begin{array}{c}\text { Plot and } \\
\text { Building } \\
\text { (Million USD) }\end{array}$ & $\begin{array}{l}\text { Own capital } \\
\text { (Million USD) }\end{array}$ & $\begin{array}{l}\text { Promissory } \\
\text { notes and } \\
\text { Bonds issued by } \\
\text { the State and } \\
\text { private sectors } \\
\text { (Million USD) }\end{array}$ & $\begin{array}{l}\text { The rating of } \\
\text { the share of } \\
\text { the life } \\
\text { insurance } \\
\text { premium in } \\
\text { Gross } \\
\text { Domestic } \\
\text { Product }\end{array}$ & $\begin{array}{c}\text { Rating of } \\
\text { financial } \\
\text { market } \\
\text { Fitch }\end{array}$ \\
\hline Australia & 5904 & 3248 & 7601 & 50436 & 18 & AAA \\
\hline Belgium & 8723 & 10423 & 19321 & 225757 & 16 & AA \\
\hline Denmark & 12215 & 1643 & 149180 & 120153 & 6 & AAA \\
\hline Germany & 15986 & 35732 & 162106 & 912979 & 25 & AAA \\
\hline Italy & 8604 & 6429 & 69022 & 565366 & 8 & BBB- \\
\hline $\begin{array}{l}\text { United } \\
\text { Kingdom }\end{array}$ & 94573 & 4911 & 19324 & 368602 & 4 & AA \\
\hline Sweden & 10511 & 12774 & 152763 & 145404 & 10 & AAA \\
\hline Switzerland & 19884 & 47866 & 21560 & 197350 & 13 & AAA \\
\hline Spain & 20020 & 13003 & 18252 & 257081 & 31 & A- \\
\hline Latvia & 117 & 21 & 10 & 664 & 82 & A- \\
\hline Lithuania & 59 & 8 & 16 & 765 & 64 & $\mathbf{A}$ \\
\hline Georgia & 59 & 6 & 71 & $\mathbf{0}$ & 118 & BB- \\
\hline
\end{tabular}

SOUrCe: 1. ORGANISATION FOR ECONOMIC CO-OPERATION AND DEVELOPMENT; LEPL InSUrance State Supervision Service of Georgia 2019

2. The World Bank, TCdata360.

https: //tcdata360. worldbank.org/indicators/hbae5670f?country=BRA\&indicator $=41585 \&$ viz=line chart\&years $=2017$

3. Fitch Ratings: Credit Ratings \& Analysis For Financial Markets, https://www.fitchratings.com/

The statistics in the table shows, that the country that has a developed insurance market, volume of investing in the securities market is high (Belgium, Denmark, Germany, Italy, the United Kingdom, etc.), which is in compliance with the rating of the life accumulative insurance and is confirmed by the ratings given by the rating company- Fitch to the financial markets of these countries in 2020. Maintaining the BBrating of Georgia's financial market is not conditioned by increasing the capitalization of financial institutions, but by the developing and implementing a corporative governance code in the banking sector. The conducted research showed that the hypothesis "A developed insurance market-a developed financial 
market" has been justified. The situation of Georgia's financial institutions confirms it, which enables the reveal of existing problems and formulates proposals to improve the financial situation.

In order to have a complete picture of the impact of the financial market on the development of the regional economy, we have analysed the situation in the Georgian Stock market. Despite the fact that the global stock exchanges had collapsed under the influence of COVID-19 in March 2020, the rapid and coordinated action of the monetary and fiscal policies by the side of the developed countries reduced the impact of the pandemic on the economy. In response to the pandemic, the majority of the central banks had reduced their interest rates. Besides, the fiscal expenditures made in order to support the households and companies, amounted 12 trillion US dollars. The devaluation of currencies caused by the capital outflows in our region, had decreased the ability of central banks to reduce their interest rates. As a result of the unprecedented monetary and fiscal stimulations carried out by the leading economics, the index of global capital (including the best outcomes was demonstrated by stocks of the technology companies) was increased since May 2020 and later, parallel to the increased capital flows the income on the bonds of the developed countries had been decreased.

Some stock markets stand even on the higher benchmark compared to the last year and the Swiss Stock Exchange is among them, which was awarded by AAA rating by the rating company Fitch. The US stock markets ended 2020 with the positive results at the expenses of shares of companies operating in the field of technology, telecommunications and the Internet. Indexes of NASDAQ which are formed by the shares of Facebook, Amazon and Netflix companies were increased by $40 \%$ during one year. Japanese index on the Asian market Nikkei was increased by $20 \%$, Stock exchange market of Shankhai was risen by $-15 \%$. It is true that the European index is also rising, however, they have not reached the level of the pre-crisis period yet. The German DAX index rose by $4 \%$, while the French CAC 40 is $6 \%$ lower than it was in the last year, and UK FTSE100 index is $9 \%$ lower than it was in January 2020. The media reported as if the correlation connection between the real economics and the financial markets had been violated. Why has the situation on the stock exchanges normalized when the pandemic is having a strong impact on the economies of the leading countries? Since the first panic caused by the pandemic had calmed-down, the investors observed that a significant portion of the economics was in a good shape, which explains the rise of securities markets. An important role in this was played, of course, by the State, which had provided a significant assistance to the private sector, as well as large central banks with their expansionist monetary policy. As a result, despite the uncertain state of the economy, the basic financial and macroeconomic indicators are not so bad. As for the current events in Georgian stock market, the encouraging policy implemented by the National Bank of Georgia and the Government, the development of the government's debt securities market and the seek for the alternative financing by the side of the businesses, facilitated the development of debt securities. As the conducted research showed, the role of the banking sector in the development of the financial market is high, but the role of insurance companies is low, especially in the development of securities, which is reflected in the above indicated table. The local stock market is inactive, in developing countries like Georgia, it is more interesting for private company owners to seek financial resources through the debt instruments than to issue shares and, consequently, to relinquish control / governance. Therefore, development of this market may be considered as an intermediate circle between the traditional crediting and the use of other capital market instruments. However, in recent years, the market of the securities has increased significantly, these are the securities which enable the owner to receive a fixed interest rate (income) and return the borrowed amount, within a certain/specified period. It includes: State Treasury liabilities; Savings certificates; Bill (promissory note); Bond. From 31 December 
2014 to 31 October 2019, their volume had been increased from 56 million GEL to 500 million dollar's equivalents in GEL (Figure 5).

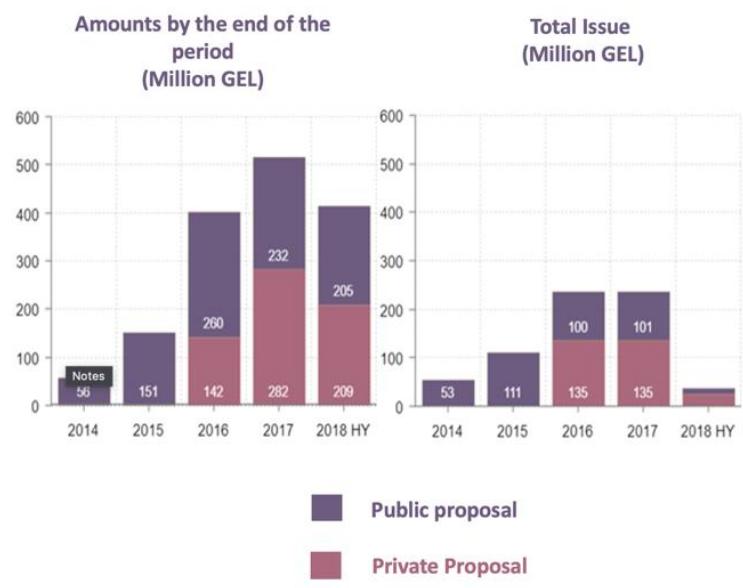

Source: Georgian Stock Exchange and the National Bank of Georgia

Figure 5. Corporate debt securities issued in the local market

The issuance of GEL-denominated debt securities by international financial institutions had been also increased and by the state of June 30, 2018, and it amounted to 717 million GEL. Nevertheless, the share of the Georgian capital market is about $10 \%$ of the financial sector's assets. It should be noted that, during the recent years the rise of demand of bonds in Georgia was promoted by different features of Georgian business environment. First of all, it should be noted that the profitability of Georgian State Eurobond GEORGIA 21, in the beginning of the year 2020, amounted $2.4 \%$ and the existing spread (difference) in comparison to the other instruments with comparable rating (BB) was quite low. Against the background of the financial crisis caused by the pandemic, in March 2020, the profitability of GEORGIA 21 increased sharply and amounted $6.2 \%$ at the end of March. However, due to the reduced risk in the region during the summer months, GEORGIA 21's profit began to decline and the spread with comparable countries also decreased significantly. It is also noteworthy, that despite the political uncertainty regarding Georgia's parliamentary elections (October 2020), the income of GEORGIA 21 was not changed significantly. By the end of 2020, the income on the sovereign Eurobond had dropped significantly- to $0.8 \%$. It should also be noted, that the Eurobond expires in April 2021 and according to the 2021 budget document, refinancing of Eurobond is being planned. Georgia had placed \$500 million ten-year Eurobonds on the London Stock Exchange in 2011, the principal repayment date of which is April 2011. As for the treasury bonds, it is true that the size of the local bond market in Georgia is quite small and illiquid, compared to other local markets in the region, despite this, it is trying to occupy an important place in the stock market. Its profitability is closely linked to the monetary policy rate, which amounts $8 \%$ from August 2020. Commercial banks remain its largest owners with $-71 \%$. The local corporative bonds occupy the important place in Georgian stock market. In 2020 three bonds were placed in the local market:

1) TBC Leasing - In March 2020, TBC issued a 3-year bond worth GEL 54 million, with a floating coupon rate TIBR3 $+3.25 \%$ (which is $11.35 \%$ as of January 2021 );

2) Georgian Leasing Company (GLC) refinanced its existing 10 million bonds in August with a new, 2year, $7.5 \%$ bond; 
3) Kakhetian Traditional Winery (KTW) - one of the largest representatives of wine and spirits in Georgia - placed the first \$10 million bond on the Georgian Stock Exchange in December 2020, the bond coupon rate is $9.0 \%$, the term is 3 years.

\section{Conclusions and recommendations}

Although the pandemic is not over yet and determination of the volume of its influence on the stock market, the state of which despite the measures taken by the National bank, is not still in a good condition and is not able to compete with other sectors of financial market, it could be said, that it is not possible yet, however it does not show the sharply negative directions.

1) For the further development of the capital market, the role of the National band and government of Georgia in the development of securities market is important. Along with the growth of the economics, it is important to create the relevant supportive environment, for which the consequential implementation of a long-term strategy is important, which requires active actions.

2) Despite the measures taken by the National Bank, the liquidity needed for the banking system was not provided during the crisis, which increased the liquidity risk in the banking system and forced the banks to reduce lending even more sharply. All of this, in the end, is reflected in a significant decline of lending economy. As the analysis showed, banks are reducing to give loans due to the expectation of receiving potential losses. This, in turn, further slows-down economic activity and the negative spiral will be repeated. Accordingly, it is necessary to be aware of the following:

- appropriate supportive environment means a stable macroeconomic environment, sustainable, transparent and efficient functioning of the financial sector and legislative and regulatory framework, which ensures the protection of investor's rights and market's credibility;

- existence of various stimulating (tax) policies;

- developed government bond market, coherence and compliance with international standards of the Georgian capital market;

- existence of a variety of financial instruments, raising the level of financial education and so on.

3) Quality assessment in the development of regional economies of financial institutions gives a pessimistic picture on bases of the conducted research. Foreign experiences of economic development are based on the use of effective mechanisms of financial market development, among them, the American and Western European approaches are considered as the successful models, so-called institutional matrix. In Georgia, despite its orientation to the West course, an approach towards the financial institutions as the independent business entities has not been implemented yet, which is evident in the degree of competition. As the study shows, individual insurance companies perform profitably in the reporting year, but their role in the development of the financial market and consequently in the growth of the economy is insignificant. In our opinion, this is not a problem created by one company, it is based on the socio-economic situation, which occupies the first place in the development of the insurance sector. Accordingly, the authors believe that:

- the problem of unemployment should be solved first, the average salary should correspond to the average standard of living;

- the introduction of accumulative life insurance should become a priority of the Government, which will be achieved by compulsory insurance of employed citizens, otherwise the insurance sector will remain only an individual protection mechanism and will not fulfil the role of supplying free capital market. 


\section{Bibliography}

1. A Tsintsadze, I Vashakmadze, Irina Tavadze, Lilit Meloyan-Phutkaradze, PERSPECTIVES AND OPPORTUNITIES OF GEORGIAN FINANCIAL MARKET INTEGRATION INTO EU,ECONOMIC SCIENCE FOR RURAL DEVELOPMENT 2020, 131

2. A.I. Luchenka "Institutions rule the economy" (2018) (own bibliography)

3. Annual Financial stability report 2020. Retrieved: https://www.nbg.gov.ge/uploads/publications/finstability/2020/finstability_2020_geo.pdf . Access: 13.01 .21

4. Bank journal. Security Market Blog. Retrieved: www.nbg.gov.ge. Access: 20.12 .20

5. Bank of Georgia - Ratings Navigator. Retrieved: https://www.fitchratings.com. Access: 15.01.20

6. Financial Stability Report, 2019. Retrieved: https://www.nbg.gov.ge/uploads/publications/finstability/finstability_2019_eng_publish_3.pdf. Access: 04.01 .21

7. GALT \& TAGGART CREATING OPPORTUNITIES. Retrieved: 29 January 2021

8. Joaquin Maudosa, Juan Fernandez de Guevara. (2015). The Economic Impact of European Financial Integration: The Importance of the Banking Union. The Spanish Review of Financial Economics. Vol.13. Issue 1. pp. 11-19

9. JorgFinsinger,(2019). EuropeanMarketIntegrationandtheEuropeanInsuranceIndustry:ReasonsforTrade, Barriers to Entry, Distribution Channels, Regulation and Price Levels, Tax Harmonization and Financial Liberalization in Europe pp 225-261.

10. Klaus Weber Gerald F. Davis and Michael LounsburyDeveloping Stock Exchanges In Developing Countries, FINANCE \& ACCOUNTING POLICY JUN 1, 2011

11. LEPL Insurance State Supervision Service of Georgia. Retrieved: https://www.insurance.gov.ge. Access: 23.01.20

12. Mckinnon, R. I. (1973). Money and Capital in Economic Development. Washington, D. C.: Brookings Institution.

13. Organisatiion for Economic Co-operation and Development. Retrieved: https://stats.oecd.org/Index.aspx?QueryId=25444. Access: 02.02.20

14. Phutkaradze,B.,Tsintsadze,A.,PhutkaradzeZ.(2019)FinancialIntegrationandEconomicGrowth:Empirical Evidence from the Republic of Georgia. European Journal of Sustainable Development 8 (2),pp. 232-232.

15. Regulations Implemented according to the Retail Lending. Retrieved: https://www.nbg.gov.ge/index.php?m=726. Access: 05.02.20

16. Selvarajan S.K, Rossazana A, (2020), Financial Integration and Economic Growth: Should Asia Emulate Europe? Vol. 35, No. 1, pp. 191-213.

17. Shaw, E. (1973), Financial Deepening in Economic Development. New York: Oxford University Press.

18. Stiglitz, Joseph (2004). "Capital-Market Liberalization, Globalization, and the IMF," Oxford Review of Economic Policy, Vol. 20, No. 1, pp. 57-71.

19. Tsintsadze, A., Meloyan-Phutkaradze, L.(2017). Empirical Analysis of Development of Insurance Field. Scientific letters of academic society of Michal Baludansky, 5, pp. 146-149.

20. Tsintsadze, A., Oniani, L., Ghoghoberidze, T. (2018) Determining and Predicting Correlation of Macroeconomic Indicators on Credit Risk caused by Overdue Credit, Banks \& bank systems, Issue13, Iss. 3, pp. 114-119.

21. Tsintsadze, A., Vashakmadze, I., Tavadze, I., Meloyan-Phutkaradze, L.(2019). New Regulations in the Development of a Financial Market. American Journal of Fundamental, Applied \& Experimental Research 12 (1), pp. 96-101.

22. Vashakmadze, I., (2018). Problematic Loan Management in Georgian Commercial Banks. Ukraine-EU. Innovations in education, technology, business and law, p. 334.

23. Vashakmadze, I., Glonti, V.(2018). Deposit Insurance, as the Basis for Ensuring Financial Sustainability of the Banking System. Journal of Applied Finance and Banking 8 (5), pp. 43-52. 